\title{
Effect of Pinching and Spraying of Paclobutrazol on Vegetative Growth, Flowering and Chemical Composition of Zinnia elegans, Jacq. Sharaf-Eldien, M. N. ${ }^{1}$; Samia Z. El-Bably ${ }^{2}$ and M. R. Magouz $^{2}$ \\ ${ }^{1}$ Dept. Veg. \& Flori., Fac. Agric., Mansoura Univ., Egypt. \\ ${ }^{2}$ Hort. Res. Inst., Agric. Res. Center, Giza, Egypt.
}

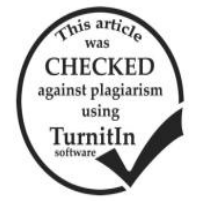

\section{ABSTRACT}

This investigation was carried out in the Experimental Farm of Sakha Horticulture Research Station, Kafr El- Sheikh, during two successive seasons of 2014 and 2015 to investigate the effect of pinching and foliar spray of paclobutrazol (PBZ) at 0, 50, 100 and 150 ppm as well as interaction with them on growth, flowering and chemical composition of Zinnia elegans as pot plant. The obtained results revealed that the pinching increased stem diameter, number of branches and flowers/plant, fresh and dry weights of vegetative parts and flowers/plant, and N, P and K percentages but decreased plant height, leaf area, flower diameter as well as chlorophyll $a, b$ and $(a+b)$ contents. PBZ treatments caused an increase in the stem diameter, number of branches and flowers/plant, chlorophyll $a, b$ and $(a+b)$ as well as $\mathrm{P}$ and $\mathrm{K}$ percentages, while decreased plant height, fresh and dry weight of vegetative parts and flowers/plant and flower diameter. Concerning the interaction, shortest plant height, the largest number of branches and flowers/plant and the highest amount of chlorophyll content were obtained with pinching and $150 \mathrm{ppm}$ PBZ treatment. It may be concluded that the pinching and treated with $\mathrm{PBZ}$ at 100 or $150 \mathrm{ppm}$ gave a good feature for potted Zinnia elegans plants.

\section{INTRODUCTION}

Zinnia elegans belongs to family Asteraceae, is an annual plant, growing as bedding, cut flowers and can also be used as flowering potted plant. However, production of zinnia as a pot-plant is not short and compact enough to produce high-quality and marketable plant (Andersen and Andersen, 2000 and Pinto et al., 2005). The aesthetic value can only be achieved by the increased number of healthy and beautiful flowers (Wainwright and Irwin, 1987 and Munir and Naz, 2006). Therefore, a technique such as pinching (manual removal of shoot apices) to overcome apical dominance and encourage lateral branching is a commercial recommendation in ornamental plant production (Lee et al., 2006; Ahmad et al., 2007; Shanan and Soliman, 2011; Dorajeerao and Mokashi, 2012 and Mutlu and Agan, 2015). Effects of pinching in terms of significant reduction in plant height, delayed flowering and increased number of flowers have been recorded in several commercial floriculture crops (Dorajeerao and Mokashi, 2012 and Mutlu and Agan, 2015). Plant growth retardants (PGRs) have been used in the field of floriculture for inducing more acceptable plant characteristics like compact growth, dwarfness and increased number of healthy branches (Cox and Keever, 1988; Banon et al., 2002; Taychasinpitak and Manochai 2003). An important group of commercial plant growth retardants are the triazol compounds such as paclobutrazol (PBZ), which suppresses growth through interference of gibberellic acid biosynthesis, a hormone responsible for cell elongation (Fletcher et al., 2000 and Rademacher, 2000). Therefore, the objective of this study was to evaluate the effects of manual pinching and PBZ on the growth of Zinnia elegans and to identify the best procedure for production of zinnia as commercial pot plant.

\section{MATERIALS AND METHODS}

This study was carried out in a polyethylenecovered green house, in the Experimental Farm of Sakha Horticulture Research Station, Kafr El- Sheikh, during two successive seasons of 2014 and 2015. Seeds were sown on the March 1st in both seasons in polyethylene plug trays filled with a mixture of peatmoss and vermiculite $(2: 1 \mathrm{v} / \mathrm{v})$. One month from sowing, the uniform seedlings about 9-10 $\mathrm{cm}$ height were transplanted into $16 \mathrm{~cm}$ diameter plastic pot filled by the same medium, single seedling was planted per pot. After one week from transplanting, the plants of Zinnia elegans were divided into two groups, in the first group the apical buds were removed (pinched) while in the second group they were without pinching (non- pinched). Both groups were twice sprayed with PBZ ([(4chlorophenyl) methyl]-a-(1,1-dimethylethyl)-1H-1,2,4triazole-1-ethanol) at four concentrations $(0,50,100$ and $150 \mathrm{ppm})$ at 3 and 21 days after pinching. Spray applications were done in early morning till the solution run off, while control plants $(0)$ were sprayed with distilled water only.

All plants were fertilized with $4 \mathrm{~g} /$ plant calcium super phosphate $(15.5 \% \mathrm{P} 2 \mathrm{O} 5)$ in one dose at the soil preparation before transplanting, $8 \mathrm{~g} /$ plant ammonium sulphate $(20.5 \% \mathrm{~N})$ and $4 \mathrm{~g} /$ plant potassium sulphate $(48.5 \%$ K2O). Nitrogen and potassium fertilizer were divided into two equal doses, the first dose was added after two weeks from transplanting and the second one was added three weeks later according to El Morsy (2011). However, all plants received the usual agricultural practices.

The following data were recorded at the end of production cycle (six to seven open inflorescences per plant); plant height (from main stem base to inflorescence receptacle insertion, $\mathrm{cm})$, stem diameter $(\mathrm{cm})$, leaf area (cm2) was calculated using the formula according to Gardner et al., (1985), number of branches and flowers/plant, fresh and dry weight of vegetative parts and flowers $(\mathrm{g}) /$ plant, flower diameter $(\mathrm{cm})$, chlorophyll a, b and chlorophyll $(\mathrm{a}+\mathrm{b})$ (the fifth leaf from the top of the plant) according Moran (1982), total nitrogen (\% of dry weight) in the leaves was determined using microkjeldahl as described by Black (1965), phosphorus (\% of dry weight) in the leaves was estimated colorimetrically as recommended by Jackson (1973), as well as potassium (\% of dry weight) in the leaves was determined using flame photometer method described by Cottenie et al. (1982). The leaves were dried in an electrical oven at $50 \mathrm{oC}$ till constant dry weight before chemical analysis.

A factorial experiment in a randomized completely block design was applied with two factors: (1) pinched and non-pinched, (2) four concentrations of PBZ. Each of the 8 treatments of the experiment had 
three replicates each replicate contained three pots. Data were statistically analyzed by using MSTAT program and means were compared by Duncan's Multiple Range Test at 0.05 level (Snedecor and Cochran, 1980).

\section{RESULTS}

\section{Vegetative growth plant height}

Data in Table (1), reveal that the pinching reduced plant height than unpinched plants by 11.76 and $14.37 \%$ in the first and second seasons, respectively. PBZ at different rates showed significant effect on the plant height and 150 ppm concentration produce highly reduction by 23.87 and $43.23 \%$ in the first and second seasons, respectively compared to control (sprayed with water). Concerning the combined effects of the pinching and PBZ treatments, it is clear from the data presented in Table (1), that the shortest plants were obtained in pinched plants and treated with PBZ at the high rate $(150 \mathrm{ppm})$ and this decrease was 32.53 and $54.36 \%$ in the first and second seasons, respectively compared to unpinched and PBZ untreated plants, which had maximum length.

\section{Stem diameter}

It is obvious from the data presented in Table (1), that pinching significantly increased stem diameter than unpinched plants by 4.35 and $6.36 \%$ for the first and second seasons, respectively. Stem diameter increased with increasing rate of PBZ spraying and the differences among them were significant. The high concentration of PBZ led to increase this parameter by 14.94 and $14.95 \%$ in the first and second seasons, respectively compared to control. Concerning the effect of interaction, the treatment of PBZ at $150 \mathrm{ppm}$ in pinched plants gave the highest value in this respect. Such increase was 23.53 and $26.96 \%$ compared to unpinched and PBZ untreared plants in the first and second seasons, respectively.

Number of branches/plant

Data presented in Table (1), show that the pinching significantly increased number of branches/plant than unpinched plants by 57.63 and $20.18 \%$ in the first and second seasons, respectively. All concentrations of PBZ also increased number of branches/plant compared with control. Concerning the effect of interaction, the treatment of PBZ at $100 \mathrm{ppm}$ in pinched plants gave the highest value in this regard. Such increase was 106.22 and $45.86 \%$ in the first and second seasons, respectively compared to unpinched and PBZ untreated plants.

\section{Leaf area}

Significant reduction in leaf area was recorded in pinched plants (Table 1), reduction reached up to 4.60 and $5.26 \%$ compared to unpinched plants in both seasons, respectively. Leaf area was reduced by increasing concentrations of PBZ. At the highest concentration of $\mathrm{PBZ}$, reduction reached up to 12.30 and $20.25 \%$ in the both seasons, respectively compared to control. Maximum reduction was recorded in pinched plants and treated with $\mathrm{PBZ}$ at $150 \mathrm{ppm}$, reduction reached up to 42.54 and $25.49 \%$ compared to unpinched and untreated plants in both seasons, respectively.

Table 1. Effect of pinching, paclobutrazol (PBZ) treatments and their interaction on plant height, stem diameter, number of branches/plant and leaf area of Zinnia elegans during 2014 and 2015 seasons.

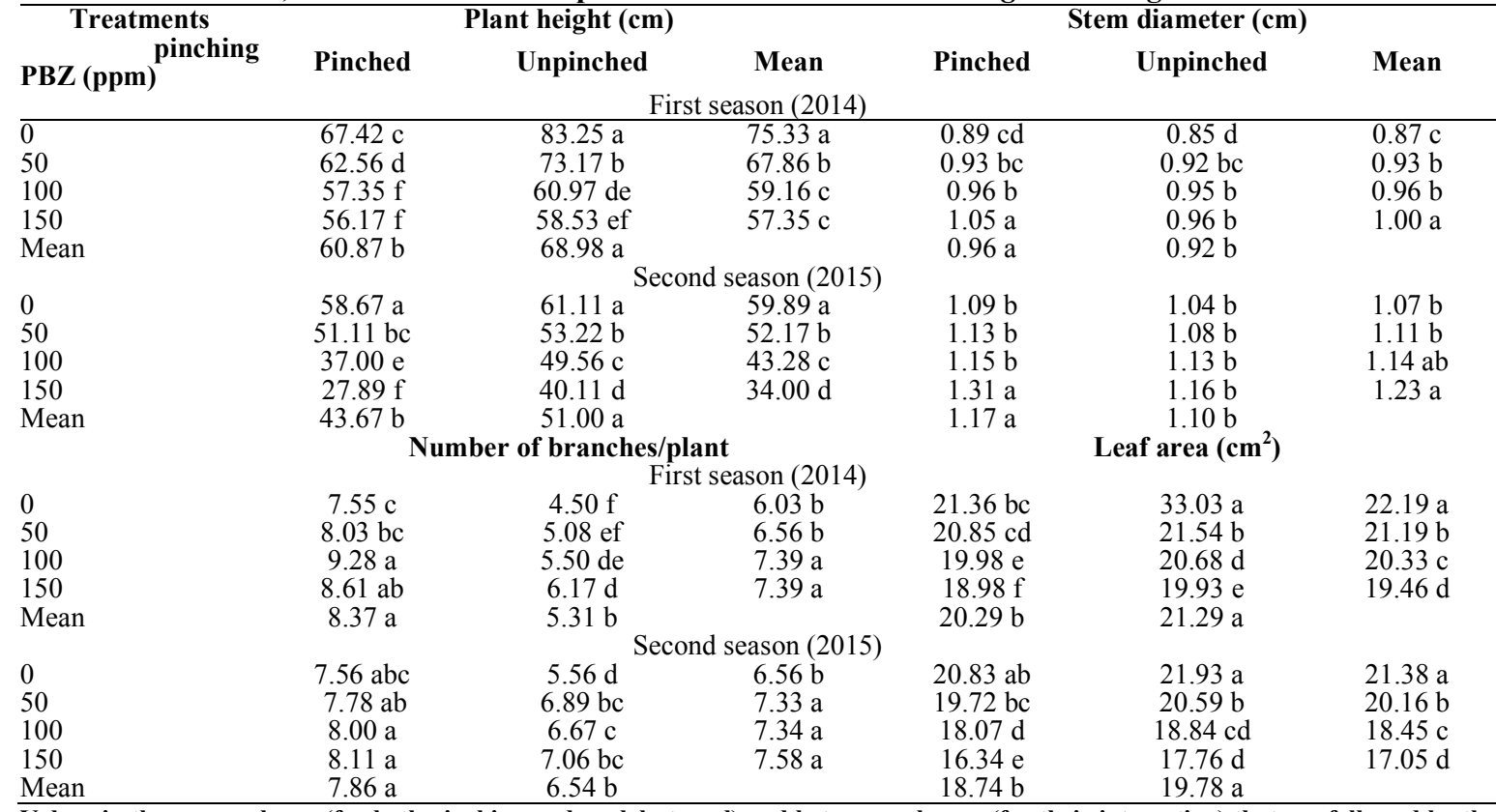

Values in the same column (for both pinching and paclobutrazol) and between columns (for their interaction) that are followed by the same letters do not differ significantly according to Duncan's Multiple Range Test at the 5\% level.

Fresh and dry weight of vegetative parts/plant Data in Table (2) show that pinching tretment increased fresh and dry weights of vegetative parts/plant than unpinched plants by 6.52 and $8.00 \%$ for fresh weight in the first and second seasons, respectively and $6.47 \%$ for dry weight in second season, whereas the increasing for dry weight in the first season was non-significant. Fresh and dry weight of vegetative parts/plant decreased with increasing rate of PBZ, the high concentration of PBZ (150 ppm) decreased this parameter by 19.37 and $26.36 \%$ for 
fresh weight and 33.95 and $40.27 \%$ for dry weight in the first and second seasons, respectively compared to control. Concerning the effect of interaction, the treatment of PBZ at $150 \mathrm{ppm}$ on unpinched plants gave the lowest value for fresh weight. Such decrease was 18.54 and $26.84 \%$ in the first and second seasons, respectively compared to unpinched and PBZ untreated plants. While the lowest value for dry weight was resulted from PBZ at $150 \mathrm{ppm}$ on pinched plants. The reduction was about 37.29 and $39.56 \%$ in the first and second seasons, respectively compared to unpinched and PBZ untreated plants.

\section{Flowering}

\section{Number of flowers/plant}

Data in Table (2) show that the pinching significantly increased number of flowers/plant than unpinched plants by 6.19 and $5.17 \%$ in first and second seasons, respectively. PBZ increased number of flowers/plant with all rates and $100 \mathrm{ppm}$ rate gave the highest value. Such increase was 38.31 and $12.58 \%$ in the first and second seasons, respectively compared with control. Concerning the effect of interaction, the treatment of PBZ at $100 \mathrm{ppm}$ in pinched and unpinched plants gave the highest value in this concern. This increase was 43.39 and $20.14 \%$ in pinched plants and 41.67 and $17.42 \%$ in unpinched plants in the first and second seasons, respectively compared to unpinched and PBZ untreated plants.

\section{Flower diameter}

Data presented in Table (2) reveal that the pinching decreased flower diameter than unpinched plants by 5.78 and $1.74 \%$ for the first and second seasons, respectively. PBZ at different rates show decreased flower diameter, the highest PBZ concentration (150 ppm) decreased this parameter by 8.34 and $7.12 \%$ in the first and second seasons, respectively than control. Concerning the effect of interaction, the treatment of PBZ at $150 \mathrm{ppm}$ in pinched plants gave the lowest value in this respect. Such decrease was 12.51 and $9.22 \%$ in the first and second seasons, respectively compared to unpinched and PBZ untreated plants.

Table 2. Effect of pinching, paclobutrazol (PBZ) treatments and their interaction on fresh and dry weight of vegetative parts/plant, number of flowers/plant and flower diameter of Zinnia elegans during 2014 and 2015 seasons.

\begin{tabular}{|c|c|c|c|c|c|c|}
\hline \multirow{2}{*}{$\begin{array}{l}\frac{\text { Treatments }}{\text { pinching }} \\
\text { PBZ (ppm) }\end{array}$} & \multicolumn{3}{|c|}{$\begin{array}{c}\text { Fresh weight of vegetative } \\
\text { parts/plant (g) }\end{array}$} & \multicolumn{3}{|c|}{$\begin{array}{l}\text { Dry weight of vegetative } \\
\text { parts/plant (g) }\end{array}$} \\
\hline & Pinched & Unpinched & Mean & Pinched & Unpinched & Mean \\
\hline \multicolumn{7}{|c|}{ First season (2014) } \\
\hline 0 & $127.33 \mathrm{a}$ & $118.67 \mathrm{~b}$ & $123.00 \mathrm{a}$ & $61.71 \mathrm{a}$ & $58.57 \mathrm{~b}$ & $60.14 \mathrm{a}$ \\
\hline 50 & $117.00 \mathrm{~b}$ & $107.33 \mathrm{c}$ & $112.17 \mathrm{~b}$ & $57.57 \mathrm{~b}$ & $51.61 \mathrm{c}$ & $54.59 \mathrm{~b}$ \\
\hline 100 & $105.33 \mathrm{c}$ & $101.00 \mathrm{~d}$ & $103.17 \mathrm{c}$ & $49.37 \mathrm{~d}$ & $52.65 \mathrm{c}$ & $51.01 \mathrm{c}$ \\
\hline 150 & $101.67 \mathrm{~d}$ & $96.67 \mathrm{e}$ & $99.17 \mathrm{~d}$ & $36.73 \mathrm{f}$ & $42.70 \mathrm{e}$ & $39.72 \mathrm{~d}$ \\
\hline Mean & $112.83 \mathrm{a}$ & $105.92 \mathrm{~b}$ & & $51.35 \mathrm{a}$ & $51.38 \mathrm{a}$ & \\
\hline \multicolumn{7}{|c|}{ Second season (2015) } \\
\hline 0 & $119.00 \mathrm{a}$ & $112.03 \mathrm{~b}$ & $115.52 \mathrm{a}$ & $58.26 \mathrm{a}$ & $51.54 \mathrm{~b}$ & $54.90 \mathrm{a}$ \\
\hline 50 & $109.72 \mathrm{~b}$ & $98.02 \mathrm{c}$ & $103.87 \mathrm{~b}$ & $48.60 \mathrm{c}$ & $41.90 \mathrm{e}$ & $45.25 \mathrm{~b}$ \\
\hline 100 & $90.80 \mathrm{~d}$ & $85.50 \mathrm{ef}$ & $88.15 \mathrm{c}$ & $45.09 \mathrm{~d}$ & $44.11 \mathrm{de}$ & $44.60 \mathrm{~b}$ \\
\hline 150 & $88.17 \mathrm{de}$ & $81.96 \mathrm{f}$ & $85.07 \mathrm{c}$ & $31.15 \mathrm{~g}$ & $34.42 \mathrm{f}$ & $32.79 \mathrm{c}$ \\
\hline Mean & $101.93 \mathrm{a}$ & $94.38 \mathrm{~b}$ & & $45.77 \mathrm{a}$ & $42.99 \mathrm{~b}$ & \\
\hline \multicolumn{4}{|c|}{ Number of flowers/plant } & \multicolumn{3}{|c|}{ Flower diameter $(\mathrm{cm})$} \\
\hline \multicolumn{7}{|c|}{ First season (2014) } \\
\hline$\overline{0}$ & $6.82 \mathrm{c}$ & $6.43 \mathrm{c}$ & $6.63 \mathrm{c}$ & $8.54 \mathrm{bc}$ & $8.95 \mathrm{a}$ & $8.75 \mathrm{a}$ \\
\hline 50 & $8.40 \mathrm{ab}$ & $7.83 \mathrm{~b}$ & $8.12 \mathrm{~b}$ & $8.20 \mathrm{~d}$ & $8.91 \mathrm{a}$ & $8.56 \mathrm{a}$ \\
\hline 100 & $9.22 \mathrm{a}$ & $9.11 \mathrm{a}$ & $9.17 \mathrm{a}$ & $8.02 \mathrm{de}$ & $8.55 \mathrm{~b}$ & $8.29 \mathrm{~b}$ \\
\hline 150 & $9.20 \mathrm{a}$ & $8.30 \mathrm{ab}$ & $8.75 \mathrm{a}$ & $7.83 \mathrm{e}$ & $8.20 \mathrm{~cd}$ & $8.02 \mathrm{c}$ \\
\hline Mean & $8.41 \mathrm{a}$ & $7.92 \mathrm{~b}$ & & $8.15 \mathrm{~b}$ & $8.65 \mathrm{a}$ & \\
\hline \multicolumn{7}{|c|}{ Second season (2015) } \\
\hline$\overline{0}$ & $7.78 \mathrm{ab}$ & $7.00 \mathrm{~b}$ & $7.39 \mathrm{c}$ & $8.70 \mathrm{~b}$ & $9.00 \mathrm{a}$ & $8.85 \mathrm{a}$ \\
\hline 50 & $7.89 \mathrm{ab}$ & $7.44 \mathrm{~b}$ & $7.67 \mathrm{~b}$ & $8.57 \mathrm{bc}$ & $8.67 \mathrm{bc}$ & $8.62 \mathrm{~b}$ \\
\hline 100 & $8.41 \mathrm{a}$ & $8.22 \mathrm{a}$ & $8.32 \mathrm{a}$ & $8.43 \mathrm{~cd}$ & $8.53 \mathrm{bc}$ & $8.48 \mathrm{~b}$ \\
\hline 150 & $7.66 \mathrm{ab}$ & $7.50 \mathrm{~b}$ & $7.58 \mathrm{~b}$ & $8.17 \mathrm{e}$ & $8.27 \mathrm{de}$ & $8.22 \mathrm{c}$ \\
\hline Mean & $7.93 \mathrm{a}$ & $7.54 \mathrm{~b}$ & & $8.47 \mathrm{~b}$ & $8.62 \mathrm{a}$ & \\
\hline
\end{tabular}

Values in the same column (for both pinching and paclobutrazol) and between columns (for their interaction) that are followed by the same letters do not differ significantly according to Duncan's Multiple Range Test at the 5\% level.

Fresh and dry weight of flowers/plant

It is obvious from the data presented in Table (3), that pinching significantly increased fresh weight by 6.01 and $5.23 \%$ and dry weight by 5.92 and $5.57 \%$ than unpinched plants for the first and second seasons, respectively. Increasing PBZ doses significantly reduced fresh and dry weight of flowers/plant compared to control in both seasons. However, 150 ppm dose had the greatest reducing effect in both seasons, reduction reached up to 25.42 and $8.18 \%$ for fresh weight and 27.32 and $9.76 \%$ for dry weight in both seasons, respectively. The interaction revealed that $\mathrm{PBZ}$ at the highest dose produced similar reduction on pinched and unpinched plants.

\section{Chemical composition}

Chlorophyll (a), (b) and chlorophyll (a+b) content $\left(\mathrm{mg} / \mathrm{cm}^{2}\right)$

Data in Table (3 and 4) show that pinching decreased chlorophyll (a) by 22.99 and $17.19 \%$, chlorophyll (b) by 22.22 and $30.30 \%$ and chlorophyll $(\mathrm{a}+\mathrm{b})$ contents by 22.72 and $21.65 \%$ in the first and second seasons, respectively compared to unpinched plants. It is clear from Table (3 and 4) that PBZ increased chlorophyll (a), (b) as well as chlorophyll $(\mathrm{a}+\mathrm{b})$ contents with all rates 
and $150 \mathrm{ppm}$ rate gave the highest values in these parameters. Such increase were 183.78 and $196.43 \%$ for chlorophyll (a), 194.74 and $225.00 \%$ for chlorophyll (b) and 189.29 and $55.12 \%$ for chlorophyll $(\mathrm{a}+\mathrm{b})$ contents in the first and second seasons, respectively compared to untreated plants. Concerning the effect of interaction, PBZ with pinched and unpinched treatments increased chlorophyll (a), (b) and $(\mathrm{a}+\mathrm{b})$ contents as the effect increased gradually with increasing the rate. However, the highest increase was obtained from plants treated with PBZ at the highest dose $(150 \mathrm{ppm})$ in unpinched plants, the increase were 140.00 and $169.69 \%$ for chlorophyll (a), 110.71 and $238.46 \%$ for chlorophyll (b) and 129.49 and $189.13 \%$ for chlorophyll $(\mathrm{a}+\mathrm{b})$ contents in the first and second seasons, respectively compared to unpinched and PBZ untreated plants.

Table 3. Effect of pinching, paclobutrazol (PBZ) treatments and their interaction on fresh and dry weight of flowers/plant and chlorophyll (a) and (b) contents of Zinnia elegans during 2014 and 2015 seasons.

\begin{tabular}{|c|c|c|c|c|c|c|}
\hline \multirow{2}{*}{$\begin{array}{l}\frac{\text { Treatments }}{\text { pinching }} \\
\text { PBZ (ppm) }\end{array}$} & \multicolumn{3}{|c|}{ Fresh weight of flowers/plant (g) } & \multicolumn{3}{|c|}{ Dry weight of flowers/plant (g) } \\
\hline & Pinched & Unpinched & Mean & Pinched & Unpinched & Mean \\
\hline \multicolumn{7}{|c|}{ First season (2014) } \\
\hline$\overline{0}$ & $58.98 \mathrm{a}$ & $58.32 \mathrm{ab}$ & $58.65 \mathrm{a}$ & $14.28 \mathrm{a}$ & $14.12 \mathrm{a}$ & $14.20 \mathrm{a}$ \\
\hline 50 & $57.94 \mathrm{ab}$ & $52.56 \mathrm{bc}$ & $55.25 \mathrm{ab}$ & $14.25 \mathrm{a}$ & $12.87 \mathrm{ab}$ & $13.56 \mathrm{ab}$ \\
\hline 100 & $54.62 \mathrm{abc}$ & $50.92 \mathrm{c}$ & $52.77 \mathrm{~b}$ & $13.14 \mathrm{ab}$ & $12.26 \mathrm{~b}$ & $12.70 \mathrm{~b}$ \\
\hline 150 & $45.01 \mathrm{~d}$ & $42.46 \mathrm{~d}$ & $43.74 \mathrm{c}$ & $10.57 \mathrm{c}$ & $10.07 \mathrm{c}$ & $10.32 \mathrm{c}$ \\
\hline Mean & $54.14 \mathrm{a}$ & $51.07 \mathrm{~b}$ & & $13.06 \mathrm{a}$ & $12.33 \mathrm{~b}$ & \\
\hline \multicolumn{7}{|c|}{ Second season (2015) } \\
\hline$\overline{0}$ & $53.80 \mathrm{ab}$ & $52.54 \mathrm{ab}$ & $53.17 \mathrm{a}$ & $13.02 \mathrm{a}$ & $12.58 \mathrm{ab}$ & $12.80 \mathrm{a}$ \\
\hline 50 & $51.30 \mathrm{ab}$ & $48.83 \mathrm{bc}$ & $50.07 \mathrm{~b}$ & $12.23 \mathrm{ab}$ & $11.53 \mathrm{ab}$ & $11.88 \mathrm{ab}$ \\
\hline 100 & $49.71 \mathrm{abc}$ & $48.22 \mathrm{bc}$ & $48.97 \mathrm{~b}$ & $11.98 \mathrm{ab}$ & $11.62 \mathrm{ab}$ & $11.80 \mathrm{ab}$ \\
\hline 150 & $51.33 \mathrm{ab}$ & $46.32 \mathrm{c}$ & $48.82 \mathrm{~b}$ & $12.05 \mathrm{ab}$ & $11.05 \mathrm{~b}$ & $11.55 \mathrm{~b}$ \\
\hline Mean & $51.54 \mathrm{a}$ & $48.98 \mathrm{~b}$ & & $12.32 \mathrm{a}$ & $11.67 \mathrm{~b}$ & \\
\hline \multicolumn{4}{|c|}{ Chlorophyll (a) (mg/g) } & \multicolumn{3}{|c|}{ Chlorophyll (b) (mg/g) } \\
\hline \multicolumn{7}{|c|}{ First season (2014) } \\
\hline$\overline{0}$ & $0.24 \mathrm{e}$ & $0.50 \mathrm{~d}$ & $0.37 \mathrm{c}$ & $0.10 \mathrm{e}$ & $0.28 \mathrm{~d}$ & $0.19 \mathrm{~d}$ \\
\hline 50 & $0.75 \mathrm{c}$ & $0.86 \mathrm{bc}$ & $0.81 \mathrm{~b}$ & $0.33 \mathrm{~cd}$ & $0.41 \mathrm{bc}$ & $0.37 \mathrm{c}$ \\
\hline 100 & $0.80 \mathrm{~b}$ & $0.90 \mathrm{~b}$ & $0.85 \mathrm{~b}$ & $0.42 \mathrm{bc}$ & $0.50 \mathrm{ab}$ & $0.46 \mathrm{~b}$ \\
\hline 150 & $0.89 \mathrm{bc}$ & $1.20 \mathrm{a}$ & $1.05 \mathrm{a}$ & $0.56 \mathrm{a}$ & $0.59 \mathrm{a}$ & $0.56 \mathrm{a}$ \\
\hline Mean & $0.67 \mathrm{~b}$ & $0.87 \mathrm{a}$ & & $0.35 \mathrm{~b}$ & $0.45 \mathrm{a}$ & \\
\hline \multicolumn{7}{|c|}{ Second season (2015) } \\
\hline$\overline{0}$ & $0.22 \mathrm{e}$ & $0.33 \mathrm{~d}$ & $0.28 \mathrm{~d}$ & $0.10 \mathrm{f}$ & $0.13 \mathrm{e}$ & $0.12 \mathrm{~d}$ \\
\hline 50 & $0.54 \mathrm{c}$ & $0.60 \mathrm{c}$ & $0.57 \mathrm{c}$ & $0.20 \mathrm{~d}$ & $0.34 \mathrm{bc}$ & $0.27 \mathrm{c}$ \\
\hline 100 & $0.61 \mathrm{c}$ & $0.72 \mathrm{~b}$ & $0.67 \mathrm{~b}$ & $0.28 \mathrm{c}$ & $0.39 \mathrm{ab}$ & $0.34 \mathrm{~b}$ \\
\hline 150 & $0.76 \mathrm{~b}$ & $0.89 \mathrm{a}$ & $0.83 \mathrm{a}$ & $0.33 \mathrm{c}$ & $0.44 \mathrm{a}$ & $0.39 \mathrm{a}$ \\
\hline Mean & $0.53 \mathrm{~b}$ & $0.64 \mathrm{a}$ & & $0.23 \mathrm{~b}$ & $0.33 \mathrm{a}$ & \\
\hline
\end{tabular}

Values in the same column (for both pinching and paclobutrazol) and between columns (for their interaction) that are followed by the same letters do not differ significantly according to Duncan's Multiple Range Test at the $5 \%$ level.

Table 4. Effect of pinching, paclobutrazol (PBZ) treatments and their interaction on chlorophyll (a+b) content, nitrogen, potassium and phosphorus percentages of Zinnia elegans during 2014 and 2015 seasons.

\begin{tabular}{|c|c|c|c|c|c|c|}
\hline Treatments & & phyll $(a+b)($ & & & $\mathrm{N}(\%)$ & \\
\hline PBZ (ppm) & Pinched & Unpinched & Mean & Pinched & Unpinched & Mean \\
\hline & & & son (201 & & & \\
\hline$\overline{0}$ & $0.34 \mathrm{f}$ & $0.78 \mathrm{e}$ & $0.56 \mathrm{~d}$ & $3.03 \mathrm{a}$ & $2.66 \mathrm{abc}$ & $2.85 \mathrm{a}$ \\
\hline 50 & $1.08 \mathrm{~d}$ & $1.27 \mathrm{bcd}$ & $1.18 \mathrm{c}$ & $3.03 \mathrm{a}$ & $2.85 \mathrm{ab}$ & $2.94 \mathrm{a}$ \\
\hline 100 & $1.22 \mathrm{~cd}$ & $1.40 \mathrm{bc}$ & $1.31 \mathrm{~b}$ & $2.47 \mathrm{bcd}$ & $2.19 \mathrm{~d}$ & $2.33 \mathrm{~b}$ \\
\hline 150 & $1.45 \mathrm{ab}$ & $1.79 \mathrm{a}$ & $1.62 \mathrm{a}$ & $2.75 \mathrm{ab}$ & $2.2 \mathrm{~cd}$ & $2.52 \mathrm{~b}$ \\
\hline Mean & $1.02 \mathrm{~b}$ & $1.32 \mathrm{a}$ & & $2.82 \mathrm{a}$ & $2.50 \mathrm{~b}$ & \\
\hline & & & ason $(20$ & & & \\
\hline$\overline{0}$ & $0.32 \mathrm{f}$ & $0.46 \mathrm{e}$ & $0.78 \mathrm{~d}$ & $2.71 \mathrm{ab}$ & $2.38 \mathrm{bc}$ & $2.54 \mathrm{ab}$ \\
\hline 50 & $0.74 \mathrm{~d}$ & $0.94 \mathrm{c}$ & $0.84 \mathrm{c}$ & $2.85 \mathrm{a}$ & $2.38 \mathrm{bc}$ & $2.61 \mathrm{a}$ \\
\hline 100 & $0.89 \mathrm{c}$ & $1.11 \mathrm{~b}$ & $1.00 \mathrm{~b}$ & $2.66 \mathrm{ab}$ & $1.91 \mathrm{~d}$ & $2.29 \mathrm{~b}$ \\
\hline 150 & $1.09 \mathrm{~b}$ & $1.33 \mathrm{a}$ & $1.21 \mathrm{a}$ & $2.52 \mathrm{abc}$ & $2.15 \mathrm{~cd}$ & $2.33 \mathrm{~b}$ \\
\hline Mean & $0.76 \mathrm{~b}$ & $0.97 \mathrm{a}$ & & $2.68 \mathrm{a}$ & $2.21 \mathrm{~b}$ & \\
\hline & & $\mathbf{P}(\%)$ & & & K (\%) & \\
\hline & & & son (201 & & & \\
\hline$\overline{0}$ & $0.18 \mathrm{bc}$ & $0.16 \mathrm{c}$ & $0.17 \mathrm{~b}$ & $1.69 \mathrm{~b}$ & $1.70 \mathrm{~b}$ & $1.69 \mathrm{c}$ \\
\hline 50 & $0.19 \mathrm{abc}$ & $0.18 \mathrm{abc}$ & $0.19 \mathrm{~b}$ & $1.97 \mathrm{~b}$ & $1.97 \mathrm{~b}$ & $1.97 \mathrm{~b}$ \\
\hline 100 & $0.21 \mathrm{abc}$ & $0.20 \mathrm{abc}$ & $0.21 \mathrm{ab}$ & $2.34 \mathrm{a}$ & $1.82 \mathrm{~b}$ & $2.08 \mathrm{ab}$ \\
\hline 150 & $0.24 \mathrm{a}$ & $0.23 \mathrm{ab}$ & $0.24 \mathrm{a}$ & $2.63 \mathrm{a}$ & $1.84 \mathrm{~b}$ & $2.24 \mathrm{a}$ \\
\hline Mean & $0.20 \mathrm{a}$ & $0.19 \mathrm{~b}$ & & $2.16 \mathrm{a}$ & $1.83 \mathrm{~b}$ & \\
\hline & & & ason $(20$ & & & \\
\hline 0 & $0.18 \mathrm{~b}$ & $0.18 \mathrm{~b}$ & $0.18 \mathrm{~b}$ & $1.63 \mathrm{c}$ & $1.63 \mathrm{c}$ & $1.63 \mathrm{c}$ \\
\hline 50 & $0.20 \mathrm{ab}$ & $0.20 \mathrm{ab}$ & $0.20 \mathrm{~b}$ & $1.88 \mathrm{bc}$ & $1.89 \mathrm{bc}$ & $1.89 \mathrm{bc}$ \\
\hline 100 & $0.22 \mathrm{ab}$ & $0.22 \mathrm{ab}$ & $0.22 \mathrm{ab}$ & $2.19 \mathrm{~b}$ & $1.80 \mathrm{bc}$ & $1.99 \mathrm{ab}$ \\
\hline 150 & $0.26 \mathrm{a}$ & $0.25 \mathrm{a}$ & $0.25 \mathrm{a}$ & $2.62 \mathrm{a}$ & $1.83 \mathrm{bc}$ & $2.22 \mathrm{a}$ \\
\hline Mean & $0.22 \mathrm{a}$ & $0.21 \mathrm{~b}$ & & $2.08 \mathrm{a}$ & $1.79 \mathrm{~b}$ & \\
\hline
\end{tabular}

Values in the same column (for both pinching and paclobutrazol) and between columns (for their interaction) that are followed by the same letters do not differ significantly according to Duncan's Multiple Range Test at the 5\% level. 


\section{Nitrogen percentage in the leaves}

Data presented in Table (4) show that pinched plants had significantly increased nitrogen percentage in both seasons. This increase was 12.80 and $21.27 \%$ in the first and second seasons, respectively compared to unpinched plants. It is clear from Table (4) that nitrogen percentage significantly decreased with increasing rate of PBZ spraying except $50 \mathrm{ppm}$, which was statistically similar with control in both seasons. Concerning the combined effects of the pinching and PBZ treatments, it is clear from the data in Table (4), that the highest value was obtained from pinched plants and treated with PBZ at 50 ppm rate and such increase was 13.91 and $19.75 \%$ in the first and second seasons, respectively compared to unpinched and PBZ untreated plants.

Phosphorus and potassium percentages in the leaves

It is obvious from the data presented in Table (4), that pinching significantly increased phosphorus and potassium percentages in both seasons, as increment reached 5.26 and $4.76 \%$ for phosphorus and 18.03 and $16.20 \%$ for potassium in the first and second seasons, respectively. Plants showed an increase in the phosphorus and potassium percentages as PBZ concentrations increased. The highest PBZ concentration increased these parameters by 41.18 and $38.89 \%$ for phosphorus and 32.54 and $36.20 \%$ for potassium in the first and second seasons, respectively compared to the control. The interaction revealed that, the maximum contents of the $\mathrm{P} \%$ were obtained in plants sprayed with all doses of PBZ regardless pinch treatment. For content of $\mathrm{K} \%$ it was clear that pinched plants and treated with the highest dose of PBZ gave the highest potassium percentage, with increase 54.71 and $60.74 \%$ in the first and second seasons, respectively compared to unpinched and PBZ untreated plants. However, this result was parallel with the data obtained on the effect of these factors on most vegetative and flowering characters as shown in Table (1 and 2).

\section{DISCUSSION}

It is obvious from the aforementioned results (Table, 1-4) that pinching reduced plant height, leaf area, flower diameter and chlorophyll content, while stem diameter, number of branches/plant, fresh and dry weight of vegetative parts/plant, number of flowers/plant and fresh and dry weight of flowers/plant increased. Several studies also reported that apical bud pinching induced significant reduction in plant height and increased number of branches and flowers/plant (Jhon and Paul, 1995; Garner et al., 1997; Pathania et al., 2000; Kumar and Singh, 2002 and Dorajeerao and Mokashi, 2012).

Pinching is commonly practiced to overcome apical dominance and promote lateral branching, resulting in a large number of inflorescences and make the pot plant well shaped, more compact and attractive (Munir and Naz, 2006; Shanan and Soliman, 2011 and Mutlu and Agan, 2015).

The results indicated that PBZ at highest rate increased number of branches/plant to 66.20 and $31.41 \%$ for pinched and unpinched plants, respectively (mean of both seasons) while, pinching plants without PBZ application increased it to $50.10 \%$ (mean both seasons). Moreover, number of branches was directly proportional to the concentration of the PBZ. It is also clear from the results that number of flowers/plant are correlated with number of branches/plant, but flower diameter was small. Armitage et al., (1981) and Chen et al., (1993) also found that daminozide $\left(5.0 \mathrm{~g} \mathrm{~L}^{-1}\right)$ and PBZ $\left(0.25\right.$ or $\left.0.75 \mathrm{~g} \mathrm{~L}^{-1}\right)$ reduced inflorescence diameter of Zinnia elegans cultivars.

In data cleared that all used concentrations of PBZ caused a decrease fresh and dry weight of vegetative parts and flowers/plant. The obtained results show similarity to findings by Gibson and Whipker, (2003) and Hojjati et al., (2009), who reported that PBZ treatments reduced the growth of Osteospermum and Zinnia elegans, respectively. However, higher PBZ rate induced more branching but size of these branches remained small, with reduced leaf area, they cause some decrease in the photosynthesis rate in the plant, which decrease plant fresh and dry weight. This result may be attributed to the PBZ treatments decreased the nitrogen content that led to decrease in protein content. However, these results are in accordance to those of Kim and Suzuki (1989) who found that treatments of growth retardants reduced sink activity in side branches and inhibit assimilated ${ }^{13} \mathrm{C}$ translocation from leaves to other zinnia organs. Plant growth retardants (like PBZ) are mainly applied for decreasing the plant height of ornamental plants. These compounds decrease the internodes length and eliminate the apical dominance and inhibit the gibberellic acid biosynthesis. However, when the apical bud is removed or eliminate, the lateral buds have relatively high indole acetic acid concentrations which induce their elongation (Davis el al., 1988 and Rademacher, 2000). The increase in chlorophyll content with PBZ treatments in this study may be attributed to more densely packed chloroplasts per unite leaf area as a result of reduced leaf elongation and enhanced chlorophyll biosynthesis. However, triazol have been proposed to stimulate cytokinin synthesis that enhances chloroplast differentiation, chlorophyll biosynthesis, and prevents chlorophyll degradation (Fletcher et al., 2000).

As a conclusion, application PBZ as a foliar spray at the rate of $150 \mathrm{ppm}$ on pinched plants is recommended to improve production of potted Zinnia elegans.

\section{REFERENCES}

Ahmad, Iftikhar; K. Ziaf; M. Qasim and M. Tariq (2007). Comparative evaluation of different pinching approaches on vegetative and reproductive growth of carnation (Dianthus caryophyllus). Pak. J. Agri. Sci., 44 (4): 563-570.

Andersen, A.S. and L. Andersen (2000). Growth regulation as a necessary prerequisite for introduction of new plants. Acta Hort., 541: 183-192.

Armitage, A.M.; R.E. Bass; W.H. Carlson and L.C. Ewart (1981). Control of plant height and flowering zinnia by photoperiod and growth retardants. HortScience 16: 218-220.

Banon, S.; A. Gonzales; E.A. Cano; J.A. Franco and J.A. Fernandez (2002). Growth, development and colour response of potted Dianthus Caryophyllus cv. Mondriaan to paclobutrazol treatment. Scientia Horticulturae, 94: 371-377. 
Black, C.A. (1965). Methods of Soil Analysis. Amer. Soc. Agron. Inc. Publishers, Madison, USA.

Chen, C.L.; G.L. Keevr and C.F. Deneke (1993). Growth and flowering of triazol treated zinnia (Zinnia elegans) and marigold (Tagetes erecta). PGR Soc. Amer. Quarterly, 21: 169-179.

Cottenie, A.; M. Verloo; M. Velghe and R. Camerlynck (1982). Chemical Analysis of Plant and Soil. Laboratory of Analytical of Agroc. Stated Univ. Ghent-Belgium.

Cox, D.A. and G.J. Keever (1988). Paclobutrazol inhibits growth of zinnia and geranium. HortScience, 23: 1029-1030.

Davis, T.D.; G.L. Steffans and N. Sankhla (1988). Triazole plant growth regulators. Hort. Rev., 10: 63-105.

Dorajeerao, A.V.D. and A.N. Mokashi (2012). Growth analysis as influenced by pinching time in garland chrysanthemum (Chrysanthemum coronarium L.). Global J. Bio-Sci. Biotechnol. 1: 242-247.

El Morsy, Noha, A.A. (2011). Use of ornamental annual plants for aesthetization of green areas. M.Sc. Thesis, Fac. Agric., Kafr El-Sheikh Univ., Egypt.

Fletcher, R.A.; A. Gilley; N. Sankhla and T.D. Davis (2000). Triazoles as plant growth regulators and stress protectants. Hort. Rev. 24: 55-138.

Gardner, F.P.; R.B. Pearce and R.L. Mitchell (1985). Physiology of Crop Plants. Iowa State Univ. Press, Ames.

Garner, J.M.; S.A. Jones and A.M. Armitage (1997). Pinch treatment and photoperiod influence flowering of Delphinium cultivars. HortScience, 32 (1): 61-63.

Gibson, J.L. and B.E. Whipker (2003). Efficacy of plant growth regulators on growth on vigorous Osteospermum cultivars. Hort. Tech., 13: 132-135.

Hojjati, M.; N. Etemadi and B. Baninasab (2009). Effect of paclobutrazol and cycocel on vegetative growth and flowering of zinnia (Zinnia elegans). Agric. Sci. Technol. Nat. Resour., 47: 649-656.

Jackson, M.L. (1973). Soil Chemical Analysis. PrenticeHall of India, Private Limited, New Delhi.

Jhon, A.Q. and T.M. Paul (1995). Influence of spacing and pinching treatments on growth and flower production in chrysanthemum (Chrysanthemum morifolium Ramat.) cv. Flirt. Prog. Hort. 27: 57-61.
Kim, H.Y. and Y. Suzuki (1989). Changes in assimilated ${ }^{13} \mathrm{C}$ distribution and soluble acid invertase activity of Zinnia elegans induced by uniconazol, an inhibitor of gibberellin biosynthesis. Plant Physiol., 90: 316-321.

Kumar, R. and K. Singh (2002). Effect of growth regulator and shoot tip pinching on carnation. $\mathrm{J}$. Orna. Hort., 6: 134-136.

Lee, J.H.; K.S. Kim and C.Y. Song (2006). Effects of pinching and retardants on growth and flowering of Celosia argentea native to Korea. Korean J. Plant Res., 19 (5): 573-579.

Moran, R. (1982). Formula for determination chlorophyllous pigments extracted with $\mathrm{N}, \mathrm{N}-$ dimethylformamid. Plant Physiol., 69: 1376-1381.

Munir, M. and F. Naz (2006). Growth and flowering response of snapdragon after release apical dominance. J. App. Hort., 8: 25-28.

Mutlu, S.S. and E. Agan (2015). Effects of paclobutrazol and pinching on ornamental pepper. HortTechnology, 5 (25): 657-664.

Pathania, N.S.; O.P. Sehgal and Y.C. Gupta (2000). Pinching for flower regulation in Sim Carnation. J. Orna. Hort., 3: 114-117.

Pinto, A.C.R.; T.D.D. Rodrigues; I.C. Liete and J.C. Barbosa (2005). Growth retardants on development and ornamental quality of potted Lilliput Zinnia elegans Jacq. Sci. Agric., 62: 337-342.

Rademacher, W. (2000). Growth retardants: Effect on gibberellin biosynthesis and other metabolic pathways. Annu. Rev. Plant physiol. Plant Mol. Biol., 51: 501-531.

Shanan, Nermeen, T.A. and Amira, Sh. Soliman (2011). Response of snapdragon plants to pinching and growth retardants treatments. Am.-Eurasian J. Sustain. Agric., 5 (2): 150-157.

Snedecor, G.W. and W.G. Cochran (1980). Statistical Methods, $7^{\text {th }}$ ed. Iowa state Univ. Press, Ames, Iowa, U.S.A.

Taychasinpitak, T. and B. Manochai (2003). Use of growth retardant on classic zinnia (Zinnia angustifolia Kunth) to make commercial pot plant. Kasetsart J. (Nat. Sci.), 37: 243-246.

Wainwright, H. and H.L. Irwin (1987). The effects of paclobutrazol and pinching on Antirrhinum flowering pot plants. J. Hort. Sci., 62: 401-404.

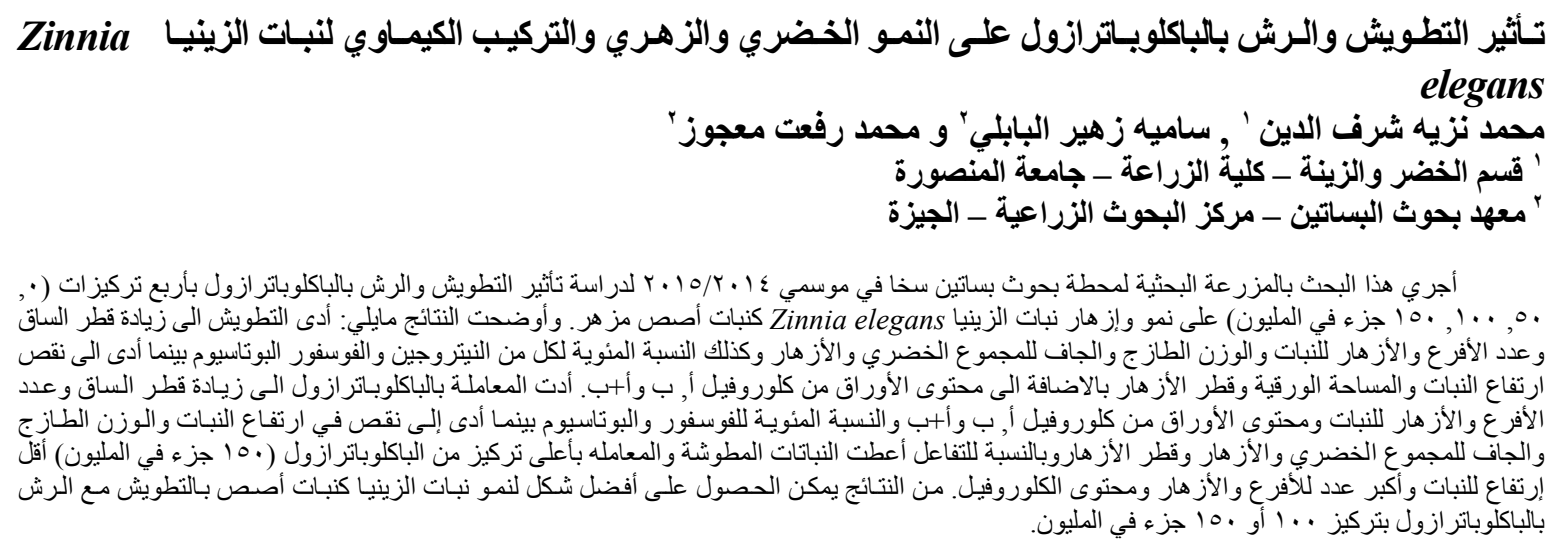

